\title{
WPEYW CZYNNIKÓW PRAWNO-PODATKOWYCH NA FUNKCJONOWANIE FUNDUSZY TYPU REITS W KRAJACH EUROPEJSKICH
}

\section{WSTEPP}

Fundusze REITs (Real Estate Investment Trusts) funkcjonuja z powodzeniem na rynkach światowych od kilkudziesięciu lat. Konstrukcja REITs pozwala na połączenie inwestycji na rynku nieruchomości z korzyściami podatkowymi na poziomie funduszu. Idea ta powstała pod koniec XIX w. w USA i miała służyć pozyskaniu kapitałów przez lokalne władze do inwestycji w miejskie nieruchomości.

W obecnej formie REITs służą do zwiększenia inwestycji na rynkach nieruchomości. Zachęta dla firm do tworzenia takich funduszy jest zwolnienie przychodów REITs z podatków. Z kolei dla inwestorów REITs czyni dostępnym kapitałochłonny rynek nieruchomości. Dodatkowo łączenie rynków finansowych i nieruchomości pozwala na zwiększenie transferu kapitałów między tymi rynkami i dywersyfikowanie portfeli inwestycyjnych inwestorów. Największym rynkiem REITs są USA (prawie jedna trzecia kapitalizacji wszystkich REITs). Z powodzeniem REITs funkcjonują także w Australii, Japonii, Singapurze, RPA i Europie.

Przełomową data dla europejskich rynków funduszy inwestycyjnych był 2007 r., w którym aż 5 krajów wprowadziło indywidualne rozwiązania prawne pozwalające zaistnieć funduszom REITs ${ }^{1}$. Działalność funduszy EU-REITs reguluje lokalne ustawodawstwo, co powoduje, że istnieją między nimi dość znaczne różnice. Celem artykułu jest analiza wpływu czynników prawno-podatkowych na funkcjonowanie REITs w krajach europejskich. Dodatkowo podjęto próbę stworzenia przykładowych modeli funduszy REITs.

\section{PIERWSZE FUNDUSZE TYPU REITS}

Jednym z najwcześniej założonych w USA funduszy był The Boston Personal Property Trust (1893 r.), który inwestował aktywa w nieruchomości. Duże zainteresowanie inwestorów tym funduszem i ponadprzeciętne wyniki inwestycyjne przyczyniły się do powstania podobnych instrumentów finansowych w innych amerykańskich miastach (m.in. Chicago, Denver, Detroit). Powodzenie tych trusts wynikało:

${ }^{1} \mathrm{~W}$ literaturze przedmiotu jest stosowany skrót EU-REITs. 
- ze szczególnych regulacji prawnych (do 1912 r. w niektórych stanach firmy mogły inwestować $\mathrm{w}$ nieruchomości tylko w celu włączenia ich do aktywów operacyjnych),

- ze zwolnienia z płacenia podatków federalnych,

- z zagwarantowania inwestorom praw korporacyjnych,

- z dostarczania kapitałów do rozbudowy miast,

- z dostępności dla wszystkich inwestorów,

$-\mathrm{z}$ wypłacania rocznych dywidend ${ }^{2}$.

Na podstawie cech - zwolnienie z podatków i wypłacanie dywidend - można uznać The Boston Personal Property Trust za prekursora funduszy REITs.

Z korzyści podatkowych fundusze nieruchomości mogły korzystać do $1935 \mathrm{r}$., w którym to Sąd Najwyższy USA zniósł część obowiązujących ulg podatkowych i zrównał je z podatkami dla firm. Rok później Kongres pod wpływem zarządzających funduszami inwestycyjnymi uchwalił Revenue Act 1936. Ustawa ta zwalniała z podatków towarzystwa funduszy inwestycyjnych, których fundusze były zdywersyfikowane (maksymalnie 5\% aktywów w jedno przedsiębiorstwo i posiadały nie więcej niż $10 \%$ wszystkich akcji jednej firmy) oraz „,chroniły” środki inwestorów ${ }^{3}$. Wprowadzone rozwiązania podatkowe nie dotyczyły istniejących funduszy nieruchomości, co spowodowało, że towarzystwa funduszy inwestycyjnych nie tworzyły nowych funduszy nieruchomości i doszło do likwidacji już funkcjonujących ${ }^{4}$ (tylko nieliczne zmieniły politykę inwestycyjna).

Regulacje prawne dotyczące działalności amerykańskich funduszy REITs wprowadzone zostały w 1960 r. ustawą REIT Act 1960. Aby fundusz mógł skorzystać z niższych podatków, musiał spełniać następujące warunki:

- wypłacać minimum 90\% dochodów akcjonariuszom w formie dywidendy (co roku);

- posiadać minimum 100 udziałowców, przy czym 5 lub mniej inwestorów nie mogło posiadać więcej niż 50\% wszystkich udziałów funduszu;

- pasywnie inwestować w nieruchomości ( $w$ tym bez możliwości zarządzania nimi),

- uzyskiwać minimum 75\% przychodów z wynajmu nieruchomości, sprzedaży nieruchomości, udziałów w innych funduszach i innych źródeł związanych z nieruchomościami;

- zainwestowanie przynajmniej 75\% aktywów w nieruchomościach, kredytach hipotecznych, gotówce i obligacjach skarbowych ${ }^{5}$.

W ostatniej ustawie regulującej działalność REITs (REIT Modernization Act 1999) przywrócono podstawowe warunki kwalifikujące fundusze jako REITs z REIT Act 1960.

${ }^{2}$ D. J. Valachi, REITs: A Historical Perspective, „The Appraisal Journal” 45, 1977, s. 450-451; S. H. Chan, J. Erickson, K. Wang, Real Estate Investment Trusts. Structure, Performance, and Investment Opportunities, Oxford 2003, s. 15.

${ }^{3}$ M. Fink, A Historical Perspective on the Investment Company Act: Lessons from the Past and Trends for the Future, ,The Investment Lawyer” 6, 2006, nr 13, s. 19.

${ }^{4}$ The Boston Personal Property Trust został zlikwidowany w 1935 r.

${ }^{5}$ S. H. Chan, J. Erickson, K. Wang, op. cit., s. 16. 
Drugim krajem, który wprowadził fundusze inwestycyjne z przywilejami podatkowymi, była Holandia. W 1969 r. zostały wprowadzone fundusze FBI (Fiscale Beleggingsinstelling), których cechą szczególną była wysokość podatku od osób prawnych ustalona na poziomie $0 \%$ oraz obowiązek dystrybucji całego dochodu wśród akcjonariuszy.

Amerykańskie REITs i holenderskie FBI spowodowały utworzenie nowego typu funduszu inwestycyjnych - funduszy lokujących aktywa na rynku nieruchomości, które mogły korzystać z ulg podatkowych. REITs zaczęły powstawać w innych krajach europejskich dopiero w latach dziewięćdziesiątych XX w. W 1995 r. w Belgii wprowadzono fundusze SICAFI (Société d'investissement en immobiliser á capital fixe/vastgoedbeleggingsvennootschap met vast kapitaal), określone jako notowane na giełdzie fundusze inwestycyjne ze zmienną liczbą akcjonariuszy, których celem jest dystrybucja zwolnionych

\section{Tabela 1}

Daty wprowadzenia funduszy typu REITs w krajach europejskich

\begin{tabular}{|l|c|l|}
\hline \multicolumn{1}{|c|}{ Kraj } & $\begin{array}{c}\text { Rok } \\
\text { wprowadzenia }\end{array}$ & \multicolumn{1}{c|}{ Rodzaj funduszu } \\
\hline Grecja & 1999 & $\begin{array}{l}\text { REMF (Real Estate Mutual Funds) } \\
\text { REIC (Real Estate Investment Companies) }\end{array}$ \\
\hline Francja & 2003 & SIIC (Sociétés d'investissement immobiliers cotées) \\
\hline Bułgaria & 2004 & SPIC (Special Investment Purpose Companies) \\
\hline Wielka Brytania & 2007 & UK-REIt (United Kingdom REIT) \\
\hline Włochy & 2007 & SIIQ (Società d'Investimento Immobiliare Quotate) \\
\hline Litwa & 2007 & REIT \\
\hline Luksemburg & 2007 & SIF (Specialised investment fund) \\
\hline Niemcy & 2007 & G-REIT (German REIT) \\
\hline Hszpania & 2009 & $\begin{array}{l}\text { SOCIMI (Sociedades Anónimas Cotizadas } \\
\text { de Inversión en el Mercado Inmobiliario) }\end{array}$ \\
\hline Finlandia & 2009 & REIT \\
\hline Turcja & 2009 & $\begin{array}{l}\text { IREIC (Infrastructure Real Estate Investment } \\
\text { Companies) }\end{array}$ \\
\hline
\end{tabular}

Źródło: opracowanie własne na podstawie EPRA, Global REIT Survey 2011, Brussels 2012.

z podatku dochodów z najmu nieruchomości ${ }^{6}$. W tym samym czasie w Turcji wprowadzono fundusze REIC (Real Estate Investment Company), które sa zwolnionymi z podatku od zysków spółkami akcyjnymi notowanymi na giełdzie w Stambule. W tabeli 1 przedstawiono w porządku chronologicznym inne kraje europejskie, w których działają fundusze typu REITs.

\footnotetext{
${ }^{6}$ EPRA, European REIT Regimes and the Impact of the EC Treaty Freedoms, Brussels 2005, s. 9.
} 


\section{CHARAKTERYSTYKA EUROPEJSKICH FUNDUSZY REITS}

Rozwój funduszy REITs w Europie był dwuetapowy. W pierwszym okresie (1969-2004) nieliczne kraje europejskie wprowadziły do swojego prawodawstwa przepisy prawne umożliwiajace ich funkcjonowanie. Były to: Belgia, Holandia, Turcja, Grecja i Bułgaria. W drugim okresie (od 2007 r.) REITs zostały utworzone $\mathrm{w}$ krajach $\mathrm{z}$ największymi rynkami funduszy inwestycyjnych (Wielka Brytania, Niemcy, Luksemburg) oraz na Litwie i we Włoszech.

\section{Angielskie fundusze UK-REITs}

UK-REITs zostały wprowadzone w Anglii w 2007 r. ustawa The Finance Act 2006. Dodatkowo ich działalność jest regulowana także przez prawo podatkowe (The Corporation Tax Act 2010). Zgodnie z obowiązującym w Wielkiej Brytanii prawem UK-REIT może funkcjonować jako notowana na londyńskiej giełdzie (lub innej uznawanej przez HM Revenue \& $\mathrm{Custom}^{7}$ ) spółka zależna od parent company. Dopuszczalne jest także funkcjonowanie UK-REIT bez parent compa$n y$ (do lutego $2011 \mathrm{r}$. nie istniał żaden taki fundusz) i posiadanie własnych spółek córek.

Zarówno parent company i UK-REITs muszą spełnić szereg warunków, aby móc skorzystać ze zwolnień podatkowych. Na poziomie przedsiębiorstwa są to:

- parent company musi być rezydentem wyłącznie Wielkiej Brytanii (w rozumieniu przepisów podatkowych) i musi funkcjonować jako zamknięty fundusz inwestycyjny (closed-ended company $)^{8}$,

- parent company musi posiadać przynajmniej 75\% akcji każdego zależnego UK-REITs i minimum 51\% akcji całej grupy,

- emituje zwykłe akcje notowane na uznanej przez HM Revenue \& Custom giełdzie,

- nie jest spółką zamknięta, czyli nie jest kontrolowana przez 5 lub więcej akcjonariuszy i minimum $35 \%$ akcji jest w obrocie publicznym (z zastrzeżeniem, że pojedynczy inwestor posiada mniej niż 5\% akcji),

- pojedynczy inwestor instytucjonalny posiada mniej niż $10 \%$ akcji z prawem głosu,

- nie jest otwartym funduszem inwestycyjnym,

- nie posiada kredytów i pożyczek wpływających na wynik finansowy i aktywa grupy $^{9}$, dystrybucja minimum $90 \%$ przychodów z wynajmu nieruchomości.

Spółki zależne mogą być rezydentami innych krajów niż Wielka Brytania, ale $\mathrm{w}$ takim przypadku zwolnione $\mathrm{z}$ podatku będą wyłącznie przychody uzyskane z nieruchomości zlokalizowanych w Wielkiej Brytanii.

Działalność inwestycyjna UK-REITs podzielona jest na podstawową i dodatkową. Dochody i zyski kapitałowe uzyskane z działalności podstawowej zwolnione sa z podatku dochodowego, gdy minimum $75 \%$ aktywów jest zain-

\footnotetext{
7 Królewski Urząd Podatkowy i Celny.

${ }^{8}$ Firma inwestycyjna emitująca określoną liczbę akcji, które są notowane na giełdzie.

${ }^{9}$ Finance Act 2006, Chapter 9.
} 
westowane w wynajmowane nieruchomości (mieszkalne i komercyjne) i 75\% całkowitych przychodów pochodzi z wynajmowanych nieruchomości i sprzedaży posiadanych nieruchomości. Dodatkowo UK-REIT musi posiadać minimum 3 nieruchomości, z czego wartość każdej z nich nie może przekraczać $40 \%$ aktywów ogółem. W ramach tej działalność dopuszczalne jest również prowadzenie projektów deweloperskich na własny użytek. Jako nieruchomość deweloperską traktuje się obiekt, którego koszt budowy przekroczył 30\% ceny zakupu. Budowa musi być zakończona w przeciagu 3 lat i obiekt nie może zostać sprzedany w pierwszych 3 latach od momentu oddania go do użytkowania. W przeciwnym razie wypracowane zyski podlegają opodatkowaniu. W działalności dodatkowej zaangażowane może być maksymalnie $25 \%$ aktywów ogółem i nie może ona przynosić więcej niż jedną czwartą przychodów. Działalność ta podlega opodatkowaniu ${ }^{10}$.

\section{Belgijskie fundusze SICAFI}

Belgijskim odpowiednikiem funduszu REIT jest SICAFI - spółka prawa handlowego o stałym kapitale, która może funkcjonować jako limited liability company (spółka $\mathrm{z}$ ograniczoną odpowiedzialnościa) lub partnership limited with shares (spółka komandytowa). Fundusz SICAFI musi być notowany na jednej z europejskich giełd papierów wartościowych, z zastrzeżeniem, że $30 \%$ akcji musi być w wolnym obrocie. Minimalny kapitał wynosi 1,25 mln euro lub jego wartość zgodna jest z wymogami giełdy, na której notowany jest fundusz. SICAFI może funkcjonować jako fundusz publiczny lub prywatny ${ }^{11}$.

SICAFI podlega ordynacji podatkowej jak inne firmy, tyle że podatek wynosi $0 \%$ i zyski kapitałowe zwolnione są od podatku. $Z$ kolei rocznym podatkiem objęte sa aktywa funduszu - publiczne SICAFI 0,08\% i prywatne $0,01 \%$.

SICAFI może lokować aktywa tylko $\mathrm{w}$ instrumenty związane $\mathrm{z}$ rynkiem nieruchomości, w tym: prawa własności do obiektów, udziały w nieruchomościach, akcje publicznych i instytucjonalnych SICAFI zarejestrowanych w Belgii oraz akcje firm związanych $\mathrm{z}$ rynkiem nieruchomości. $\mathrm{W}$ pojedynczą nieruchomość może być zainwestowane maksymalnie $20 \%$ aktywów funduszu. Dodatkowo możliwe jest inwestowanie w projekty deweloperskie (przy czym wybudowane nieruchomości moga być sprzedane dopiero po 5 latach od zakończenia budowy). Możliwe jest inwestowanie również na innych rynkach niż belgijski. W celu zmniejszenia ryzyka finansowego dopuszcza się lokowanie aktywów $\mathrm{w}$ zbywalne papiery wartościowe i niespekulacyjne instrumenty hedge ${ }^{12}$.

\section{Bułgarskie fundusze REITs}

Działalność bułgarskich REITs (BG-REITs) jest regulowana przez wprowadzoną w 2003 r. ustawę Act on the Special Investment Purpose Companies

\footnotetext{
${ }^{10}$ Ibidem.

${ }^{11}$ Fundusz publiczny kierowany jest do wszystkich inwestorów, a prywatny - do określonej przez zarządzających grupy inwestorów.

12 EPRA, Global REIT Survey 2011. Belgium, Brussels 2012, s. 3-4.
} 
(ASIPC). BG-REIT może działać tylko jako spółka akcyjna, która musi spełniać określone w ASIPC warunki. Są to między innymi:

- obowiązek notowania na giełdzie państwa z Unii Europejskiej,

- minimum $30 \%$ akcji posiadaja inwestorzy instytucjonalni ${ }^{13}$,

- działalność inwestycyjna (budowanie portfela nieruchomości) musi rozpocząć się przed upływem roku od dnia wydania pozwolenia na funkcjonowanie jako BG-REITs,

- minimalny kapitał wynosi ponad 0,25 mln euro,

- kapitał pochodzący z IPO nie może być wyższy niż 30\% kapitału założycielskiego,

- brak akcji uprzywilejowanych.

Działalność inwestycyjna BG-REITs skoncentrowana jest na bułgarskim rynku nieruchomości. Dopuszczalne są: zakup nieruchomości i udziałów, modernizacja nieruchomości i inwestowanie w projekty deweloperskie. Przy czym fundusze nie moga zajmować się utrzymywaniem ani budowaniem nieruchomości, które wchodzą w skład ich portfeli inwestycyjnych. Te zadania są zlecane firmom zewnętrznym (tzw. service companies). Za to mogą zarządzać, wynajmować, leasingować i dzierżawić. Dodatkowo dopuszczalne jest inwestowanie przez BG-REITs w obligacje hipoteczne i udziały w service companies (do $10 \%$ aktywów funduszu ${ }^{14}$.

BG-REITs korzystaja ze zwolnienia z podatków od osób prawnych, jeżeli prowadzą działalność zgodnie $\mathrm{z}$ otrzymana licencja oraz wypłacaja akcjonariuszom minimum $90 \%$ dochodu netto. Pobierany jest jedynie roczny podatek od nieruchomości w wysokości $0,1-0,45 \%$.

\section{Fińskie fundusze REITs}

Fińskie fundusze REITs (FIN-REIT) zostały wprowadzone w Finlandii w 2009 r. na mocy The Finish Act on Tax Incentives for certain Limited Companies Carrying on Residential Renting Activities. Dodatkowo działalność FIN-REIT jest regulowana przez Act on Real Estate Funds z 1997 r.

FIN-REIT może skorzystać ze zwolnienia z podatku od osób prawnych jeżeli:

- funkcjonuje jako notowana na giełdzie spółka akcyjna z siedzibą w Finlandii z kapitałem 5 mln euro,

- posiada minium 5 akcjonariuszy, z których żaden nie posiada więcej niż $5 \%$ akcji,

- minimum 80\% aktywów zainwestuje w nieruchomości mieszkalne lub udziały firm zajmujących się leasingowaniem nieruchomości mieszkalnych (również poza Finlandią),

- minimum $80 \%$ przychodu netto pochodzi z wynajmowania nieruchomości,

- pojedynczy akcjonariusze nie posiadają więcej niż 10\% akcji funduszu,

\footnotetext{
${ }^{13} \mathrm{Sa}$ to przede wszystkim banki, towarzystwa ubezpieczeniowe i inne instytucje finansowe, które podlegają Bulgarian Financial Supervision Commission.

${ }^{14}$ Act on the special investment purpose companies, Promulgated, ,State Gazette” issue No. 46 dated May 20, 2003, amended, issue No. 109 dated December 16, 2003, effective from January 1, 2004, amended and supplemented, issue No. 107 dated December 7, 2004, effective from December 7, 2004.
} 
- dystrybuuje nie mniej niż $90 \%$ przychodów netto powiększonych o niezrealizowane zyski ${ }^{15}$.

Dodatkowo fundusz może zarządzać posiadanymi nieruchomościami i inwestować $\mathrm{w}$ płynne instrumenty finansowe.

\section{Francuskie fundusze SIIC}

Francuskie fundusze nieruchomości SIIC (Sociétes d'investissements immobiliers cotées) moga funkcjonować jako notowane na giełdzie spółki akcyjne lub komandytowo-akcyjne z minimalnym kapitałem w wysokości $15 \mathrm{mln}$ euro. Dodatkowo przynajmniej 15\% akcji musi być rozproszone i dominujący akcjonariusz nie może posiadać więcej niż $60 \%$ głosów. Firmy związane z rynkiem nieruchomości mogą przekształcić się w SIIC, wykorzystując inną firmę, która jest notowaną na giełdzie spółką akcyjną z kapitałem $15 \mathrm{mln}$ euro (parent company) i posiada powyżej 95\% udziałów w SIIC lub SPPICAV ${ }^{16}$, lub w SIIC i SPPICAV. Przy przekształceniu kapitał w wysokości 15 mln euro wymagany jest tylko od parent company.

SIIC moga skorzystać ze zwolnienia z podatku od osób prawnych, gdy uzyskuja dochody $\mathrm{z}$ wynajmu nieruchomości i dystrybuuja minimum $85 \%$ dochodu z wynajmowanych nieruchomości, 50\% zrealizowanych zysków kapitałowych i $100 \%$ dywidend wynikających $\mathrm{z}$ udziałów w innych SIIC lub SPPICAV ${ }^{17}$.

Działalność inwestycyjna SIIC ogranicza się do kupowania lub budowania nieruchomości w celu ich wynajmowania i inwestycji w parent companies. Dopuszczalna jest również działalność deweloperska i obrót nieruchomościami (do $20 \%$ wartości aktywów) i leasingowanie wynajętej najemcom nieruchomości. Możliwe sa inwestycje w nieruchomości poza Francją, ale te inwestycje podlegają opodatkowaniu ${ }^{18}$.

\section{Greckie fundusze REIC i REMF}

W Grecji fundusze nieruchomości zwolnione z podatku dochodowego moga prowadzić działalność jako Real Estate Mutual Funds (REMFs) ${ }^{19}$ i Real Estate Investment Company (REIC).

\footnotetext{
${ }^{15}$ Kiinteistörahastolaki 19.12.1997/1173 (Act on Real Estate Funds), http://www.finlex.fi/fi/ laki/ajantasa/1997/19971173 (dostęp: 15.08.2012); EPRA, Global REIT Survey 2011. Finland, Brussels 2011 , s. 2.

${ }^{16}$ Sociétes de Placement á Prépondéerance Immobiliére á Capital Variable, notowane na giełdzie fundusze inwestycyjne otwarte.

${ }^{17}$ PWC, Compare and Contrast: Worldwide Real Estate Investment Trust (REIT) Regimes, 2011, s. 13.

${ }^{18}$ EPRA, Global REIT Survey 2011. France, Brussels 2012, s. 6.

19 Konstrukcja REMF zbliżona jest do trusts. Nie musi być notowany na giełdzie i może inwestować $\mathrm{w}$ nieruchomości i płynne instrumenty finansowe. Jednym z akcjonariuszy musi być instytucja finansowa. Do lutego 2011 r. w Grecji nie funkcjonował ani jeden fundusz REMF.
} 
REIC może funkcjonować tylko jako spółka akcyjna z kapitałem powyżej $29 \mathrm{mln}$ euro i notowana na giełdzie papierów wartościowych w Atenach lub na innej europejskiej giełdzie.

REIC korzysta ze zwolnienia od podatku dochodowego, ale obciążona jest podatkiem od wartości posiadanych aktywów w wysokości 10\% stopy referencyjnej Europejskiego Banku Centralnego powiększonej o 1 punkt procentowy. Fundusz REIC zobowiązany jest do dystrybucji przynajmniej $35 \%$ zysku netto w formie dywidendy, która może być wypłacona w gotówce lub zamieniona na akcje ${ }^{20}$.

Minimum 80\% aktywów REIC musi być zainwestowane w nieruchomości, które określone sa jako obiekty komercyjne ( $\mathrm{w}$ tym przemysłowe) zlokalizowane w Grecji i innych krajach należących do Europejskiego Obszaru Gospodarczego (EOG). Fundusze mogą inwestować bezpośrednio lub pośrednio przez spółki zależne (warunek - nieruchomość musi być przynajmniej w $90 \%$ własnością spółki). W pojedynczą nieruchomość może być zainwestowane nie więcej niż 25\% aktywów ogółem, a w nieruchomości zlokalizowane poza Unią Europejska maksymalnie 10\%. Działalność deweloperska możliwa jest tylko wtedy, gdy koszt budowy nie przekracza $25 \%$ wartości końcowej nieruchomości. Dodatkowo REIC może inwestować do 10\% aktywów ogółem w obligacje, depozyty bankowe i wybrane papiery wartościowe ${ }^{21}$.

\section{Hiszpańskie fundusze SOCIMI}

Hiszpańskie fundusze SOCIMI (Sociedades Anónimas Cotizadas de Inversión en el Mercado Inmobiliario) jako jedyne fundusze typu REITs nie sa zwolnione z podatku dochodowego. Podatek ten jest obniżony i wynosi $19 \%$ zamiast obowiązujących 30\%. SOCIMI może prowadzić działalność tylko jako spółka akcyjna z kapitałem $15 \mathrm{mln}$ euro i musi być notowana na giełdzie w Hiszpanii lub w innym kraju z EOG. Wymagane jest $25 \%$ akcji w wolnym obrocie i pojedynczy akcjonariusz nie może posiadać więcej niż $25 \%$ akcji. SOCIMI zobowiązane są do wypłaty w formie dywidendy nie mniej niż $90 \%$ dochodów i $50 \%$ zysków kapitałowych ${ }^{22}$.

SOCIMI musi zainwestować minimum $80 \%$ aktywów w:

- miejskie nieruchomości lub

- inne SOCIMI, lub

- zagraniczne REITs, lub

- spółki córki SOCIMI.

Fundusz musi posiadać przynajmniej 3 obiekty, a wartość każdego z nich w dniu nabycia nie może przekraczać $40 \%$ aktywów ogółem. Nieruchomość może zostać kupiona lub wybudowana przez fundusz. Kupione nieruchomości muszą być własnością SOCIMI przez minimum 3 lata. Przez taki sam okres muszą być utrzymywane akcje i udziały. Nieruchomości deweloperskie musza pozostać w funduszu aż przez 7 lat ${ }^{23}$.

\footnotetext{
${ }^{20}$ PWC, op. cit., s. 17.

${ }^{21}$ EPRA, Global REIT Survey 2011. Greece, Brussels 2012, s. 3-4.

${ }^{22}$ PWC, op. cit., s. 33.

${ }^{23}$ EPRA, Global REIT Survey 2011. Spain, Brussels 2012, s. 3.
} 


\section{Holenderskie fundusze FBI}

Holenderski fundusz nieruchomości FBI może funkcjonować jako spółka z ograniczoną odpowiedzialnością (z kapitałem 18 tys. euro), spółka akcyjna (z kapitałem 450 tys. euro) lub otwarty fundusz inwestycyjny (brak wymogów kapitałowych). W odróżnieniu od innych REITs, FBI nie musi być notowany na giełdzie papierów wartościowych, ale musi wypłacać inwestorom cały dochód (w przeciagu 8 miesięcy od zakończenia roku podatkowego). FBI korzysta z obniżonego podatku od osób prawnych w wysokości $0 \%$.

FBI może funkcjonować jako fundusz publiczny lub prywatny. W publicznym funduszu pojedynczy indywidualny inwestor nie może posiadać więcej niż $25 \%$ akcji, a instytucjonalny (łącznie z podmiotami zależnymi) $-45 \%$. W prywatnym FBI minimum 75\% akcji musi być w posiadaniu inwestorów: indywidualnych (przy czym pojedynczy inwestor nie może posiadać więcej niż $5 \%$ akcji), instytucjonalnych lub innych publicznych $\mathrm{FBI}^{24}$.

FBI może inwestować na rynku nieruchomości tylko pasywnie. Dopuszczalne są inwestycje $\mathrm{w}$ istniejące nieruchomości $\mathrm{w}$ kraju i za granicą oraz instrumenty finansowe związane $\mathrm{z}$ rynkiem nieruchomości. Działalność deweloperska jest wyłączona. Za to możliwe jest poprawienie stanu technicznego i rozbudowa nieruchomości (wartość nakładów do 30\% wartości rynkowej nieruchomości). Odbywa się to poprzez spółkę zależną od FBI, która nie korzysta z ulg podatkowych ${ }^{25}$.

\section{Niemieckie fundusze G-REITs}

Niemiecki fundusz REIT (G-REIT) jest spółka akcyjna (AG, Aktiengesellschaft) z kapitałem 15 mln euro i musi być notowany na jednej z europejskich giełd papierów wartościowych z zachowaniem $15 \%$ akcji w wolnym obrocie.

Fundusze G-REITs muszą spełniać zasadę 75/75/90, czyli inwestować minimum $75 \%$ aktywów na rynku nieruchomości, osiągać z tych inwestycji nie mniej niż 75\% przychodów i wypłacać przynajmniej 90\% przychodów. Po spełnieniu powyższych warunków G-REITs moga skorzystać ze zwolnienia podatkowego na poziomie spółki. Opodatkowanie następuje dopiero na poziomie inwestora ${ }^{26}$.

Celem inwestycyjnym G-REIT jest zbudowanie portfela nieruchomości, głównie komercyjnych, które zapewnią stabilne źródło przychodów z wynajmu. Zabronione jest inwestowanie w hotele, nieruchomości mieszkalne zbudowane przed 1 stycznia 2007 r. zlokalizowane w Niemczech oraz obrót nieruchomościami. Nieruchomość mieszkalna może być przedmiotem inwestycji funduszu tylko wtedy, gdy część mieszkalna przekracza $50 \%$ powierzchni i została wybudowana po 1 stycznia 2007 r. Z kolei zagraniczne nieruchomości nie podlegają żadnym restrykcjom. Inwestycje w te nieruchomości możliwe są tylko poprzez spółki zależne w 100\% od G-REIT.

${ }^{24}$ PWC, op. cit., s. 34 .

${ }^{25}$ EPRA, Global REIT Survey 2011. The Nederlands, Brussels 2012, s. 3-4.

${ }^{26}$ PWC, op. cit., s. 15. 


\section{Tureckie fundusze REIC i IREIC}

Tureckie fundusze nieruchomości funkcjonuja jako Real Estate Investment Company (REIC) i Infrastructure Real Estate Investment Company (IREIC).

REIC musi być spółką akcyjną, której minimum $49 \%$ akcji jest w publicznym obrocie, oraz musi mieć założyciela, którym może być osoba fizyczna lub firma. Założyciel musi posiadać powyżej $10 \%$ akcji, nie może posiadać zaległości podatkowych i zobowiązań kredytowych ${ }^{27}$. Minimum 50\% aktywów musi być zainwestowane w nieruchomości ${ }^{28}$. W odróżnieniu od innych funduszy, REIC może wypłacać dywidendy w gotówce, akcjach, gotówce i akcjach lub przeznaczyć je na rezerwy. Opodatkowanie REIC na poziomie funduszu wynosi $0 \%$.

REIC może inwestować na dwa sposoby. Jeden z nich opera się na dywersyfikacji portfela inwestycyjnego pod względem rodzaju nieruchomości i lokalizacji. Drugi zakłada specjalizację funduszu, czyli inwestowanie minimum 75\% aktywów w jedną klasę nieruchomości.

Dopuszczalne inwestycje to:

- depozyty bankowe i waluta obca (do 10\% aktywów),

- sprzedaż, kupno, wynajem i zarządzanie (budynki mieszkalne i biurowe),

- sprzedaż, kupno i wynajem (centra handlowe, hotele, szpitale, magazyny i parkingi),

- projekty deweloperskie (jako udziałowiec),

- kupno i sprzedaż niezabudowanej ziemi (jeżeli nie są częścią żadnego projektu budowlanego, to udział ziemi w portfelu inwestycyjnym nie może przekroczyć $10 \%$ ),

- wynajmowanie lub leasingowanie nieruchomości podmiotów niezależnych od funduszu ${ }^{29}$.

Dodatkowo REIC nie może funkcjonować jako firma budowlana i inwestować w nieruchomości rolne.

Z kolei IREIC może funkcjonować tylko jako spółka akcyjna, której założyciel ma powyżej 25\% akcji. Minimum 49\% akcji musi być skierowane do oferty publicznej, określonej grupy inwestorów lub inwestorów instytucjonalnych. Okres funkcjonowania funduszu jest ograniczony do czasu trwania projektów, w które zainwestował fundusz. Okres ten może zostać wydłużony, jeżeli fundusz będzie również administrował przedmiotem projektu ${ }^{30}$. IREIC inwestuje aktywa w projekty infrastrukturalne związane głównie z rolnictwem, wydobyciem, transportem, energia, infrastruktura miejską i wiejską, służbą zdrowia, systemem więziennictwa i edukacją.

Fundusze IREIC są zwolnione z podatków od osób prawnych i mają na celu zwiększenie inwestycji krajowych i zagranicznych w turecką infrastrukturę (na zasadzie partnerstwa publiczno-prawnego).

\footnotetext{
${ }^{27}$ Communiqué on principles regarding real estate investment companies, Serial VI No. 11.

${ }^{28}$ EPRA, Global REIT Survey 2011. Turkey, Brussels 2012, s. 9.

${ }^{29}$ Communiqué on principles..., passim.

${ }^{30}$ Communiqué on principles regarding infrastructure investment trusts, Serial VI No. 24.
} 


\section{Włoskie fundusze SIIQ}

Włoskie fundusze nieruchomości SIIQ (Società d’Investimento Immobiliare Quotate) mogą funkcjonować jako notowane na giełdzie spółki akcyjne z minimalnym kapitałem 0,12 mln euro ${ }^{31}$, które są rezydentami we Włoszech. Dodatkowo przynajmniej 35\% akcji musi być rozproszone i żaden akcjonariusz nie może posiadać (bezpośrednio i pośrednio) więcej niż $51 \%$ akcji z prawem głosu oraz minimum $80 \%$ aktywów musi być zainwestowane w nieruchomości.

SIIQ może skorzystać ze zwolnienia z podatku od osób prawnych i podatków regionalnych tylko od dochodów z wynajmu lub leasingu nieruchomości zlokalizowanych we Włoszech. Pozostałe dochody są opodatkowane (w tym zyski kapitałowe). Warunkiem uzyskania zwolnienia podatkowego jest dystrybucja minimum $85 \%$ zysku netto $\mathrm{z}$ wynajmowanych nieruchomości ${ }^{32}$.

SIIQ może inwestować we włoskie i zagraniczne nieruchomości lub prawa do nieruchomości. Możliwe jest także leasingowanie nieruchomości i prowadzenie projektów deweloperskich, inwestowanie w inne włoskie SIIQ oraz nienotowane na giełdzie fundusze nieruchomości, które muszą spełniać warunki wymagane dla SIIQ (warunek nabycie powyżej $95 \%$ akcji) ${ }^{33}$.

\section{PORÓWNANIE}

Przepisy prawne regulujące działalność europejskich funduszy REITs (i ich odpowiedników) można rozpatrywać na poziomie funduszu i inwestorów. Dla zarządzających funduszami największe znaczenie mają korzyści podatkowe na poziomie funduszu, możliwości inwestycyjne i ograniczenia korzystania z finansowania, z kolei dla inwestorów, a także dla zarządzających funduszem - otrzymywanie rocznych dywidend i opodatkowanie dywidend i zysków kapitałowych.

Jak wynika z danych zawartych w tabeli 2, która przedstawia zróżnicowanie zapisów w krajowych regulacjach prawnych, najsłabsze restrykcje dotyczą opodatkowania przychodów funduszy, z wyjątkiem hiszpańskich SOCIMI, które korzystaja jedynie z obniżonego podatku od osób prawnych. Ograniczenia polityki inwestycyjnej funduszy są przeważnie słabe lub średnie, tylko w Bułgarii i Finlandii są mocno restrykcyjne. Z kolei możliwości korzystania z finansowania zewnętrznego są średnie lub wysokie.

Wszystkie fundusze $\mathrm{z}$ badanych krajów podlegają obowiązkowi wypłaty zysku w formie dywidendy. Najniższy wymagany poziom dotyczy włoskich SIIQ i wynosi tylko 35\%; średnia dla pozostałych funduszy to $85 \%$. Tylko holenderskie FBI zobowiązane sa do dystrybucji całego rocznego zysku. Opodatkowanie dywidend i zysków kapitałowych na poziomie inwestorów jest w większości przypadków korzystniejsze niż opodatkowanie innych dochodów. Podatek na tym samym poziomie jest stosowany we Francji, Wielkiej Brytanii i Turcji.

\footnotetext{
${ }^{31}$ Przy czym giełda Borsa Italiana wymaga kapitałów na poziomie 40 mln euro.

32 PWC, op. cit., s. 21.

${ }^{33}$ EPRA, Global REIT Survey 2011. Italy, Brussels 2012, s. 3.
} 
Tabela 2

Zróżnicowanie struktur funduszy REITs w państwach europejskich i USA

\begin{tabular}{|l|l|c|l|l|l|l|}
\hline \multicolumn{1}{|c|}{ Kraj } & $\begin{array}{c}\text { Korzyści } \\
\text { podatkowe } \\
\text { na poziomie } \\
\text { funduszu }\end{array}$ & $\begin{array}{c}\text { Wypłata } \\
\text { dywidend }\end{array}$ & $\begin{array}{c}\text { Restrykcje } \\
\text { inwesty- } \\
\text { cyjne }\end{array}$ & $\begin{array}{c}\text { Restrykcje } \\
\text { dotyczace } \\
\text { dźwigni } \\
\text { finansowej }\end{array}$ & $\begin{array}{c}\text { Restrykcje } \\
\text { dotyczace } \\
\text { akcjo- } \\
\text { nariuszy }\end{array}$ & $\begin{array}{c}\text { Opodatko- } \\
\text { wanie } \\
\text { dywidend } \\
\text { i zysków } \\
\text { kapitało- } \\
\text { wych }\end{array}$ \\
\hline USA & +++ & 90 & +++ & ++ & ++ & niższe \\
\hline Holandia & +++ & 100 & ++ & ++ & +++ & niższe \\
\hline Belgia & +++ & 80 & +++ & ++ & +++ & niższe \\
\hline Francja & +++ & 85 & +++ & ++ & ++ & równe \\
\hline $\begin{array}{l}\text { Wielka } \\
\text { Brytania }\end{array}$ & ++ & 90 & ++ & ++ & ++ & równe \\
\hline Turcja & +++ & 50 & +++ & + & ++ & równe \\
\hline Niemcy & +++ & 90 & ++ & + & ++ & niższe \\
\hline Grecja & +++ & 35 & ++ & + & +++ & niższe \\
\hline Włochy & +++ & 85 & +++ & + & ++ & niższe \\
\hline Bułgaria & +++ & 90 & + & + & brak & niższe \\
\hline Finlandia & +++ & 90 & + & ++ & ++ & niższe \\
\hline Hiszpania & + & 90 & ++ & + & ++ & niższe \\
\hline
\end{tabular}

+++ oznacza słabe restrykcje, ++ średnie, + wysokie

* Dane szacunkowe

Wartość aktywów na lipiec 2011 r.

Źródło: opracowanie własne na podstawie EPRA, Global Survey REITs 2011, Brussels 2012; EPRA, Global REIT Survey 2011. USA, Brussels 2012, s. 2.

Nie wszystkie kraje europejskie wymagają notowania akcji funduszy REITs na giełdach papierów wartościowych, jednakże te notowane maja więcej przywilejów niż nienotowane. Dopuszczenie do publicznego obrotu akcji funduszy zwiększa ich płynność, a tym samym są atrakcyjniejsze dla inwestorów; umożliwia to im także pozyskiwanie dodatkowych środków poprzez kolejne emisje akcji i zapewnia większą transparentność działania, a tym samym większe bezpieczeństwo dla inwestorów.

Cechą charakterystyczną amerykańskich REITs jest wysoka specjalizacja, czyli inwestowanie w jedna klasę nieruchomości (fundusze dochodowe, equity REITs) z dywersyfikacją ryzyka na poziomie geograficznym. Obok equity REITs na amerykańskim rynku działaja fundusze hipoteczne (inwestujące w instrumenty finansowe zabezpieczone hipotekami) i hybrydowe (inwestuja w nieruchomości i w instrumenty finansowe rynku nieruchomości). W Europie prawie wszystkie fundusze REITs odpowiadaja amerykańskim funduszom dochodowym, $\mathrm{z}$ tą różnica, że dywersyfikacja ryzyka jest na poziomie 


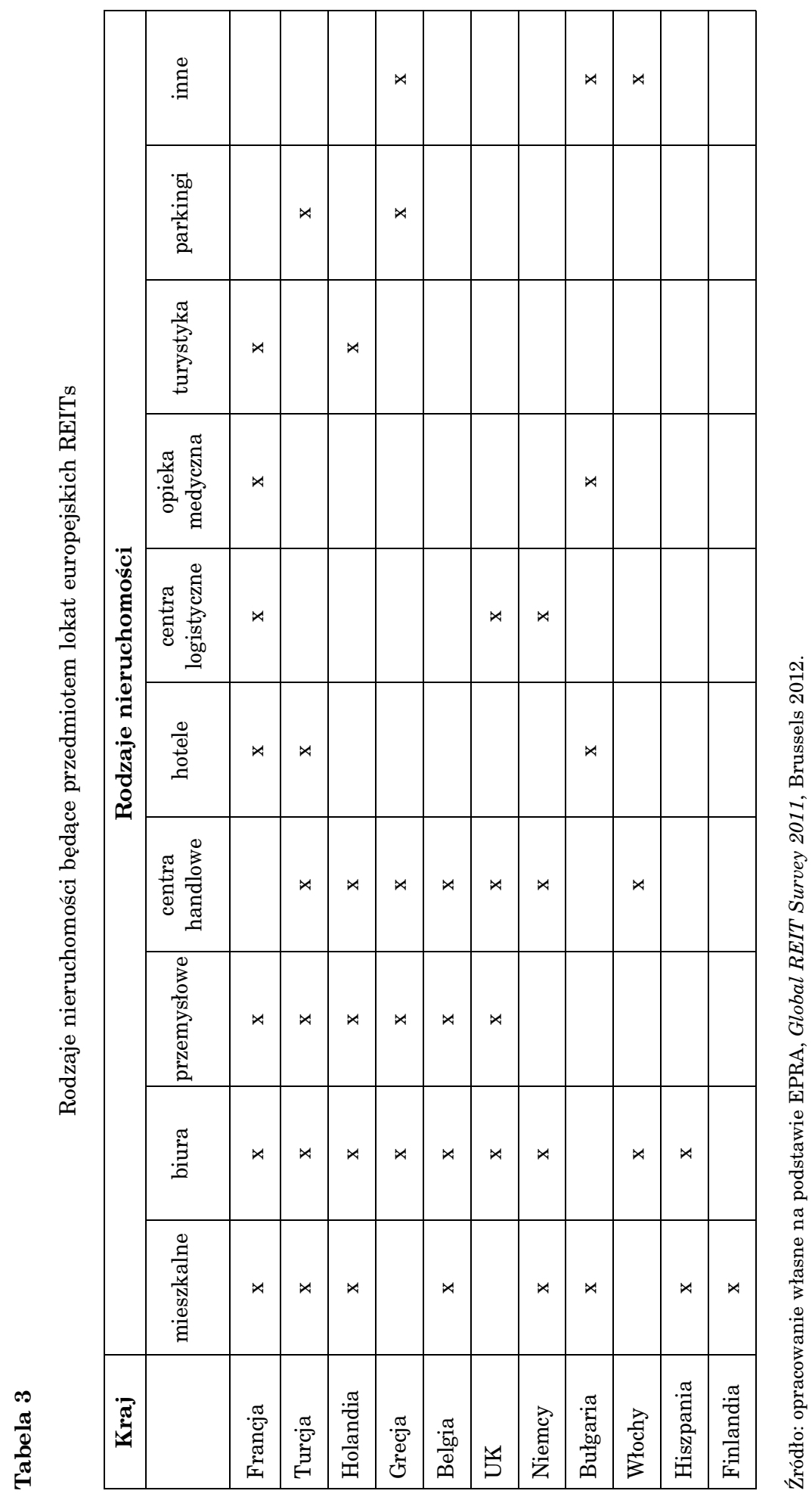


składowych portfeli inwestycyjnych - lokaty stanowią nieruchomości o różnych przeznaczeniach. Jak wynika $\mathrm{z}$ danych zawartych $\mathrm{w}$ tabeli 3 (dopuszczalne klasy nieruchomości, w które mogą inwestować europejskie fundusze REITs), najbardziej ograniczone możliwości inwestycyjne mają hiszpańskie SOCIMI (nieruchomości mieszkalne zlokalizowane $\mathrm{w}$ głównych miastach) i fińskie FIN-REITs (tylko nieruchomości mieszkalne). W pozostałych krajach katalog nieruchomości jest szerszy i obejmuje między innymi budynki mieszkalne, biura, centra logistyczne i obiekty przemysłowe.

Ograniczenia prawne wymienione powyżej maja przełożenie na wielkość lokalnych rynków funduszy REITs. Najbardziej rozwinięty i największy rynek REITs jest w USA. Według danych EPRA ${ }^{34} \mathrm{w}$ USA funkcjonuje 179 funduszy o łącznej kapitalizacji powyżej 313 mld zł. W Europie największe rynki to, kolejno Holandia (kapitalizacja 8,4 mld euro), Belgia $(5,5)$ i Francja (5).

\section{Tabela 4}

Liczba i kapitalizacja europejskich funduszy REITs i US-REITs

\begin{tabular}{|l|c|c|}
\hline \multicolumn{1}{|c|}{ Kraj } & Liczba funduszy & Kapitalizacja (mld euro) \\
\hline USA & 179 & 313,3 \\
\hline Holandia & 7 & 8,4 \\
\hline Belgia & 14 & 5,5 \\
\hline Francja & 43 & 5,03 \\
\hline Wielka Brytania & 18 & 3,09 \\
\hline Turcja & 19 & 2 \\
\hline Niemcy & 4 & 1,3 \\
\hline Grecja & 2 & 0,4 \\
\hline Włochy & 1 & 0,4 \\
\hline Bułgaria & 19 & 0,2 \\
\hline Finlandia & $1^{*}$ & bd \\
\hline Hiszpania & bd & bd \\
\hline
\end{tabular}

* Dane szacunkowe

Wartość aktywów na lipiec 2011 r.

Źródło: opracowanie własne na podstawie EPRA, Global Survey REITs 2011, Brussels 2012; EPRA, Global REIT Survey 2011. USA, Brussels 2012, s. 2.

Wynik osiaggnięty przez holenderskie fundusze wynika głównie z długiej historii rynku funduszy inwestycyjnych w Holandii i jednych z najkorzystniejszych przepisów prawnych $\mathrm{w}$ Europie. Z kolei belgijskie fundusze oferuja korzyści podatkowe na poziomie funduszu i inwestorów. Dywidendy wypłacone przez publiczny SICAFI, który inwestuje minimum 60\% aktywów w belgijskie nieruchomości mieszkalne, nie podlegaja opodatkowaniu. Nieopodatkowane sa również dywidendy otrzymane przez inwestorów indywidualnych nierezyden-

${ }^{34}$ EPRA, Global REIT Survey 2011. USA, op. cit. 
tów (warunek nieprowadzenie działalności gospodarczej w Belgii) i inwestorów instytucjonalnych (warunek nieprzerwana roczna inwestycja w SICAFI).

Najwyższa liczba funduszy jest we Francji i wynika z wysokiej specjalizacji i niskiej koncentracji rynku, z kolei w Grecji i we Włoszech - najniższa, a wynika to $\mathrm{z}$ bardzo wysokich wymogów kapitałowych (odpowiednio powyżej 29 i 40 mln euro).

\section{MODELOWE FUNDUSZE REITS}

Do zakwalifikowania funduszu nieruchomości jako REIT bierze się pod uwagę następujące cechy:

- znaczna część aktywów musi być ulokowana na rynku nieruchomości w sposób pośredni lub bezpośredni (w obiekty, projekty deweloperskie, instrumenty finansowe rynku nieruchomości),

- wypłacanie akcjonariuszom zysk lub przychody $\mathrm{w}$ formie rocznej dywidendy,

- transparentność (neutralność) podatkowa lub przywileje podatkowe (obniżone podatki od osób prawnych),

- struktura zbliżona do funduszu zamkniętego (stała liczba akcjonariuszy i kapitału),

- znaczna część przychodu musi pochodzić z najmu, sprzedaży lub leasingu nieruchomości i odsetek od instrumentów finansowych rynku nieruchomości,

- wymagana jest minimalna liczba inwestorów (określona liczbowo),

- funkcjonowanie jako spóła akcyjna i notowanie akcji na giełdzie (nieobligatoryjne).

Na podstawie powyższych cech i funkcjonujących funduszy REITs na świecie można wyróżnić dwa modele funduszy REITs: amerykański (wymaga spełnienia wszystkich podanych powyżej cech) i europejski (wymaga spełnienia pierwszych 4 cech).

Model amerykański opiera się na konstrukcji P/A/D + I (przychód/ /aktywa/dywidenda + inwestorzy), gdzie:

- P - określony procent przychodu musi być generowane z najmu i sprzedaży nieruchomości, odsetek od obligacji hipotecznych, odsetek od kredytów i pożyczek zabezpieczonych hipotecznie i dywidend z innych REITs,

- A - określona wartość aktywów musi być zainwestowana w nieruchomości lub instrumenty finansowe rynku nieruchomości,

- D - określona wartość zysku podlega wypłacie akcjonariuszom w formie rocznej dywidendy,

- I - restrykcje dotyczące minimalnej liczby inwestorów lub rozproszonego akcjonariatu.

Amerykańskie fundusze REITs określa się jako 75/75/90 + minimum 100 inwestorów, z czego nie więcej niż 5 inwestorów indywidualnych może posiadać łącznie do 50\% akcji. Podobnie można opisać europejskie fundusze z Wielkiej Brytanii (UK-REITs), Finlandii (FIN-REITs), Hiszpanii (SOCIMI), Niemiec (G-REITs) i Włoch (SIIQ). Minimalne poziomy przychodu, aktywów, dywidendy i inwestorów zawiera tabela 5 . 
Tabela 5

Minimalne poziomy zmiennych P/A/D + I europejskich REITs

\begin{tabular}{|l|l|}
\hline \multicolumn{1}{|c|}{ Kraj } & \multicolumn{1}{c|}{ Minimalne poziomy zmiennych P/A/D (\%) + I } \\
\hline Wielka Brytania & $75 / 75 / 90+35 \%$ w wolnym obrocie \\
\hline Finlandia & $\begin{array}{l}80 / 80 / 90+\text { maksymalnie } 10 \% \text { akcji w posiadaniu jednego } \\
\text { akcjonariusza }\end{array}$ \\
\hline Hiszpania & $80 / 80 / 95+100$ akcjonariuszy i $25 \%$ akcji w wolnym obrocie \\
\hline Niemcy & $\begin{array}{l}75 / 75 / 90+15 \% \text { w wolnym obrocie i mniej niż } 3 \% \text { wszystkich } \\
\text { akcji w posiadaniu jednego akcjonariusza }\end{array}$ \\
\hline Włochy & $\begin{array}{l}80 / 80 / 85+35 \% \text { akcji w wolnym obrocie i pojedynczy } \\
\text { akcjonariusz nie może posiadać więcej niż } 2 \% \text { wszystkich akcji }\end{array}$ \\
\hline
\end{tabular}

Źródło: opracowanie własne.

Wymagane wartości aktywów zainwestowanych na rynku nieruchomości, wysokość wypłacanych dywidend i osiąganego przychodu z nieruchomości dla wszystkich wymienionych wyżej funduszy są na zbliżonym poziomie. Różnica występuje na poziomie zmiennej. Najmniej restrykcyjne przepisy występuja w przypadku FIN-REITs, a najbardziej rygorystyczne - w Niemczech i Włoszech (ze względu na ograniczenia dla pojedynczych inwestorów).

Tabela 6

Minimalne poziomy zmiennych A/D + I europejskich REITs

\begin{tabular}{|l|l|l|}
\hline \multicolumn{1}{|c|}{ Kraj } & $\begin{array}{l}\text { Minimalne poziomy } \\
\text { zmiennych A i D (\%) }\end{array}$ & \multicolumn{1}{c|}{ Restrykcje dotyczace akcjonariuszy } \\
\hline Belgia & brak/80 & $\begin{array}{l}\text { 30\% akcji w wolnym obrocie po pierwszym roku } \\
\text { funkcjonowania funduszu }\end{array}$ \\
\hline Bułgaria & brak/90 & $\begin{array}{l}\text { przynajmniej 30\% akcji musi być w posiadaniu } \\
\text { inwestorów instytucjonalnych }\end{array}$ \\
\hline Holandia & brak/100 & uzależnione od typu funduszu (więcej w pkt III.8) \\
\hline Francja & brak/85 & $\begin{array}{l}\text { jeden akcjonariusz może posiadać do } 60 \% \text { akcji oraz } \\
\text { minimum 15\% akcjonariuszy musi posiadać do } 2 \% \\
\text { akcji z prawem głosu }\end{array}$ \\
\hline Grecja & $80 / 35$ & $\begin{array}{l}\text { przynajmniej } 51 \% \text { musi być w posiadaniu jednej lub } \\
\text { kilku instytucji finansowych }\end{array}$ \\
\hline Turcja (REIC) & $\begin{array}{l}50 / \text { ustalane } \\
\text { indywidualnie }\end{array}$ & przynajmniej $25 \%$ akcji w wolnym obrocie \\
\hline Turcja (IREIC) & $\begin{array}{l}75 / \text { ustalane } \\
\text { indywidualnie }\end{array}$ & $\begin{array}{l}\text { przynajmniej } 49 \% \text { akcji w wolnym obrocie lub } \\
\text { w posiadaniu określonej grupy inwestorów }\end{array}$ \\
\hline
\end{tabular}

Źródło: opracowanie własne. 
Model europejski oparty jest tylko na 3 zmiennych - aktywach, dywidendzie i inwestorach (tabela 5). W Belgii, Bułgarii, Holandii i Francji nie ma określonego poziomu wartości aktywów, która musi być zainwestowana na rynku nieruchomości. Z kolei w Grecji poziom ten wynosi 80\% i w Turcji - 75\%. Najniższy poziom dochodu funduszu, który musi zostać wypłacony akcjonariuszom, wymagany jest od greckich REIC i wynosi tylko 35\%. W przypadku tureckich REIC i IREIC poziom rocznej dywidendy ustalany jest przez fundusz z Capital Markets Board (odpowiednik polskiego KNF) w takiej wysokości, aby nie zaszkodzić strukturze finansowej i kapitałowej funduszu.

\section{POLSKIE FUNDUSZE NIERUCHOMOŚCI A REITS}

W Polsce fundusze nieruchomości moga funkcjonować tylko jako fundusze inwestycyjne zamknięte i moga być skierowane do wszystkich inwestorów lub tylko do określonej grupy. Zgodnie $\mathrm{z}$ obowiązującymi przepisami prawa ${ }^{35}$ fundusz nieruchomości ma 24 miesiące na zbudowanie portfela inwestycyjnego, który musi składać się z minimum 4 obiektów. Dopuszczalne są inwestycje we własność lub współwłasność nieruchomości gruntowych i budynków oraz

\section{Tabela 7}

Porównanie polskich funduszy nieruchomości z REITs

\begin{tabular}{|l|l|}
\hline \multicolumn{1}{|c|}{ REITs } & \multicolumn{1}{|c|}{ Polskie fundusze nieruchomości } \\
\hline $\begin{array}{l}\text { znaczna część aktywów musi być uloko- } \\
\text { wana na rynku nieruchomości w sposób } \\
\text { pośredni lub bezpośredni }\end{array}$ & $\begin{array}{l}\text { inwestycje pośrednie i bezpośrednie } \\
\text { w obiekty o różnym przeznaczeniu }\end{array}$ \\
\hline $\begin{array}{l}\text { wypłacanie akcjonariuszom zysku lub przy- } \\
\text { chodów w formie rocznej dywidendy }\end{array}$ & $\begin{array}{l}\text { niektóre fundusze przewiduja wypłaty dy- } \\
\text { widend }\end{array}$ \\
\hline $\begin{array}{l}\text { transparentność (neutralność) podatkowa } \\
\text { lub przywileje podatkowe }\end{array}$ & $\begin{array}{l}\text { fundusze są zwolnione z podatku od osób } \\
\text { prawnych; opodatkowanie jest na poziomie } \\
\text { inwestora }\end{array}$ \\
\hline $\begin{array}{l}\text { struktura zbliżona do funduszu zamknię- } \\
\text { tego }\end{array}$ & fundusze zamknięte \\
\hline $\begin{array}{l}\text { znaczna część przychodu musi pochodzić } \\
\text { z najmu, sprzedaży lub leasingu nierucho- } \\
\text { mości i odsetek od instrumentów finanso- } \\
\text { wych rynku nieruchomości }\end{array}$ & $\begin{array}{l}\text { po zakończeniu budowy portfela inwesty- } \\
\text { chomości) przychód pochodzi z posiadanych } \\
\text { obiektów lub prowadzonych projektów de- } \\
\text { weloperskich }\end{array}$ \\
\hline $\begin{array}{l}\text { funkcjonowanie jako spóła akcyjna i noto- } \\
\text { wanie akcji na giełdzie (nieobligatoryjne) }\end{array}$ & $\begin{array}{l}\text { fundusze maja tylko osobowość prawna; } \\
\text { możliwość notowania certyfikatów inwesty- } \\
\text { cyjnych na GPW w Warszawie }\end{array}$ \\
\hline
\end{tabular}

Źródło: opracowanie własne.

${ }^{35}$ Ustawa z 27 maja 2004 r. o funduszach inwestycyjnych, Dz. U. Nr 146, poz. 1576 ze zm. 
użytkowanie wieczyste; w jedną nieruchomość nie może być zainwestowane więcej niż $25 \%$ aktywów. Tytułem uczestnictwa w funduszu jest certyfikat inwestycyjny, który ma charakter papieru wartościowego i może zostać dopuszczony do obrotu wtórnego na GPW w Warszawie. O dopuszczeniu certyfikatów inwestycyjnych do notowań decydują zarządzający funduszami. Z 28 funduszy, które funkcjonowały na koniec 2011 r., tylko 8 wyemitowało publiczne certyfikaty inwestycyjne.

Porównanie cech polskich funduszy nieruchomości z cechami REITs pozwala zauważyć duże podobieństwo między tymi strukturami. Dominująca cecha REITs - korzyści podatkowe na poziomie funduszu - występuje również w polskich funduszach. Największe różnice są na poziomie organizacyjnym. REITs funkcjonuja jako spółki (zazwyczaj akcyjne), a polskie fundusze sa jednostkami organizacyjnymi z osobowością prawną.

Konstrukcja i zasady funkcjonowania polskich funduszy nieruchomości pozwalają stwierdzić, że są one zbliżone do europejskiego modelu REITs. Z jednej strony powoduje to, że wprowadzenie REITs do Polski będzie wymagało nielicznych zmian legislacyjnych, z drugiej - wzorowanie się na obecnym europejskim modelu może spowodować wprowadzenie zbyt restrykcyjnych przepisów i brak zainteresowania ze strony towarzystw funduszy inwestycyjnych.

\section{ZAKOŃCZENIE}

W literaturze funduszy inwestycyjnych podkreśla się znaczącą rolę czynników prawno-podatkowych dla rozwoju tego rynku. Zbyt restrykcyjne lub liberalne przepisy hamują rozwój rynku. Europejskie prawodawstwo regulujące działalność funduszy typu REITs ma na celu ochronę inwestorów. Ochrona ta zapewniana jest poprzez restrykcyjne przepisy, które między innymi:

- wykluczają pewne rodzaje nieruchomości,

- ograniczają możliwość aktywnego zarządzania posiadanymi obiektami,

- ograniczaja możliwość finansowania zewnętrznego,

- wymagają bardzo wysokich kapitałów założycielskich.

Ograniczenia te powoduja obniżenie sprawności inwestycyjnej zarządzających, co z kolei wpływa na uzyskiwanie niższych stóp zwrotu, a tym samym mniejsze zainteresowanie inwestorów. Jak pokazują grecki lub włoski rynek funduszy inwestycyjnych może dojść do braku zainteresowania ze strony towarzystw funduszy inwestycyjnych do tworzenia funduszy typu REITs: do lipca 2011 r. we Włoszech działał tylko jeden, a w Grecji - dwa.

Europejskie przepisy legislacyjne od momentu wprowadzenia $\mathrm{w}$ wielu krajach ewoluowały i stawały się coraz bardziej ,,przyjazne” funduszom. Wpływ na to miało wiele czynników, z których najważniejszymi są:

- wolniejszy od zakładanego rozwój funduszy REITs,

- lobbing środowisk finansowych, których celem było złagodzenie przepisów,

- ekspansja luksemburskich funduszy na europejskim rynku na skutek wprowadzenia najkorzystniejszych przepisów prawnych dla funduszy w Eu- 
ropie i specjalnych funduszy skierowanych tylko do inwestorów instytucjonalnych i well-informed ${ }^{36}$.

Niestety w Europie wprowadzanie zmian zostało przerwane przez kryzys finansowy z 2007 r. i nie zostało podjęte w późniejszym czasie ze względu na opracowywanie jednolitych przepisów obejmujących wszystkie kraje Unii Europejskiej.

mgr Artur A. Trzebinski

Uniwersytet Ekonomiczny w Poznaniu

arturtrzebinski@gmail.com

\section{THE IMPACT OF TAX AND LEGAL FACTORS ON THE FUNCTIONING OF REITS IN EUROPE}

\section{Summary}

Real Estate Investment Trusts (REITs) are investment funds that allow the transfer of capital between financial markets and real estate markets. Their main feature is the use of tax benefits that rely on the absence, or a significant reduction of corporate tax. This paper aims to analyse the impact of tax and legal factors on the functioning of REITs in European countries. In the first part of the paper, the origins of REITs and the principles of operation of such funds in European countries are presented. There are two schemes according to which REITs function, which are defined as an American and a European model. The main difference between these models is related to the level of restrictions contained in the national regulations. The European legislative provisions are intended to protect the interests of investors and their funds. Consequently, REITs in Europe are not free to develop their investment strategies and fully exploit the potential of local and regional real estate markets.

\footnotetext{
${ }^{36}$ Inwestor indywidualny, który wpłaca do funduszu minimum 125000 euro i otrzymał pisemne potwierdzenie $\mathrm{z}$ banku, że posiada odpowiednią wiedzę o rynku finansowym.
} 
Copyright of Journal of Law, Economics and Sociology is the property of Faculty of Law and Administration of Adam Mickiewicz University in Poznan and its content may not be copied or emailed to multiple sites or posted to a listserv without the copyright holder's express written permission. However, users may print, download, or email articles for individual use.

Właścicielem praw autorskich do „Ruchu Prawniczego, Ekonomicznego i Socjologicznego” jest Wydział Prawa i Administracji Uniwersytetu im. Adama Mickiewicza w Poznaniu. Zawartość czasopisma nie może być kopiowana, przesyłana do innych stron internetowych bądź zamieszczana na blogach bez pisemnej zgody wydawcy. Niemniej artykuły można drukować, kopiować lub przesyłać w formie elektronicznej na własny użytek. 